\title{
First record of Wissadula hernandioides (L'Hér.) Garcke (Malvoideae, Malvaceae) for the Caatinga domain in Brazil
}

\author{
Cihelio Alves Amorim ${ }^{1}$, Renata Gabriela Vila Nova de Lima ${ }^{1}$, Angélica Cândida Ferreira ${ }^{1}$, \\ José Iranildo Miranda de Melo $^{2}$
}

1 Universidade Federal Rural de Pernambuco, Programa de Pós-Graduação em Botânica, Rua Dom Manoel de Medeiros, s/n, Dois Irmãos, Recife, PE, CEP 52171-900, Brazil. 2 Universidade Estadual da Paraíba, Centro de Ciências Biológicas e da Saúde, Departamento de Biologia, Av. das Baraúnas, 351, Bairro Universitário, Campina Grande, PB, CEP 58429-500, Brazil.

Corresponding author: Cihelio Alves Amorim, alvescihelio@gmail.com.

\begin{abstract}
Wissadula hernandioides (L'Hér.) Garcke is native to Brazil and can be identified by its subshrub habit, cordate and discolor leaves with usually stellate trichomes, yellowish flowers arranged in paniculate inflorescences, and schizocarpic fruits. Before our finding, this species was recorded in Brazil only in Cerrado, Atlantic Forest, Amazon and Pantanal vegetation. The population found in Caatinga domain and Pernambuco state expands the distribution of $W$. hernandioides. A morphological description, habitat, and the current geographic distribution, as well as original drawing are provided.
\end{abstract}

Key words

Distribution, flora, Pernambuco, semiarid areas.

Academic editor: Adriano Stinca | Received 21 January 2019 | Accepted 6 April 2019 | Published 26 April 2019

Citation: Amorim CA, Lima RGVN, Ferreira AC, Melo JIM (2019) First record of Wissadula hernandioides (L’Hér.) Garcke (Malvoideae, Malvaceae) for the Caatinga domain in Brazil. Check List 15 (2): 339-343. https://doi.org/10.15560/15.2.339

\section{Introduction}

Malvaceae Juss. contains 243 genera and about 4,225 species according to Stevens (2001), distributed on all continents, presenting higher diversity in the warmer regions of the world with all terrestrial life-forms from annual herbs to trees (e.g. Judd and Manchester 1997, Bayer and Kubitzki 2003, Iamonico and Peruzzi 2014). In addition to its significant contribution to the world flora, this plant family stands out for its considerable economic value as plants of importance for food, medicine, ornamental use, and foraging (Souza and Lorenzi 2012).

In Brazil, Malvaceae is one of the most diverse families (Souza and Lorenzi 2012), being represented by
73 genera and 791 species, of which 422 species and 7 genera are endemic (BFG 2018). In total, 294 species have been recorded in the northeastern region of Brazil (BFG 2018), preferably associated with the Cerrado and Atlantic forest domains, although its representatives also inhabit the Caatinga, Amazon Rainforest, Pantanal, and Pampa (Bovini 2015).

Wissadula Medik. is a genus characterized by a staminal tube with a non-dentate apex, 3 or more locules, an equal number of free styles and locules and schizocarpic fruits (Fryxell 1988, 1997, Bovini and Baumgratz 2016). This genus includes approximately 32 species, widely distributed in the Neotropical region, which prefer sunny habitats with altered vegetation. In Brazil, 19 
species are recognized, which can be identified by variations in their leaf forms, types of trichomes, and the form and number of mericarps (Bovini and Baumgratz 2016).

Wissadula hernandioides (L'Hér.) Garcke is native to Brazil, and it was recorded in the Amazon, Atlantic Forest, Cerrado, and Pantanal domains. This species occurs in all regions of Brazil and is rarely found in the Northeast (Bovini and Baumgratz 2016), where it only presents records from the states of Bahia and Sergipe in areas of Cerrado and Atlantic Forest, respectively (Bovini 2015). In this work, we present a new record of $W$. hernandioides for the state of Pernambuco and Caatinga vegetation.

\section{Methods}

A field expedition at the Experimental Research Station of the Agronomy Institute of Pernambuco (IPA) in Caruaru-PE (08 $14^{\prime} \mathrm{S}, 035^{\circ} 55^{\prime} \mathrm{W}$; $537 \mathrm{~m}$ altitude) was carried out. The area is located in the semiarid region, where the phytogeographic domain of Caatinga predominates. The climate is BSh type with a minimum temperature of $11^{\circ} \mathrm{C}$ and a maximum of $38{ }^{\circ} \mathrm{C}$, and average annual precipitation of $694 \mathrm{~mm}$ distributed between March and August (Santos et al. 2016).

Fertile branches of $W$. hernandioides were collected and deposited at the Herbarium PEUFR. Identification was made using the monograph by Bovini and Baumgratz (2016) and through comparisons to the types. The morphological description of the vegetative and reproductive structures follows the terminology proposed by Beentje (2016) and Barroso et al. (1999) for fruits and seeds.

\section{Results}

Wissadula hernandioides (L'Hér.) Garcke, Zeitschr. Naturwiss. 63: 124 (1890)

Figure $1 \mathrm{~A}-\mathrm{K}$

Basionym. Sida hernandioides L'Hér., Stirp. Nov. 121122 (1789).

Type. Stirp. nov. 2: 121, tab. 58. 1789 (lectotype, designated by Areces and Fryxell 2007).

New record. Brazil: Pernambuco, Caruaru, Experimental Research Station of the Agronomy Institute of Pernambuco, margin of trail, $08^{\circ} 14^{\prime} 08^{\prime \prime} \mathrm{S}, 035^{\circ} 55^{\prime} 14^{\prime \prime} \mathrm{W}, 19 /$ IX/2017, C.A. Amorim, A.C. Ferreira, R.G.V.N. Lima 025 (PEUFR 54154) (Fig. 2). Only 1 individual was observed. Further collection efforts were made a year after the record in a radius of $500 \mathrm{~m}$ from the original point, but the plant was not relocated in the area.

Identification. Perennial subshrub, erect, monopodial branching, ca $1.5 \mathrm{~m}$ tall. Branches pubescent, trichomes simple and stellate, ferruginous. Stipules 0.8-1 $\mathrm{cm}$ in length, long-lanceolate, indumentum tomentose, trichomes simple and stellate. Leaves alternating spirals, petiolate; lamina $15-18 \times 6-15 \mathrm{~cm}$, membranaceous, green, discolor, cordate, apex acute, acuminate or caudate, whole or slightly curly margin, base subcordate or cordate, actinodromous venation, adaxial surface pilose with stellate trichomes distributed sparsely, abaxial surface tomentose with trichomes simple and stellate; petiole 10.5-14 cm long, tomentose, trichomes stellate. Inflorescence terminal, paniculate, broad synflorescence, $21-38 \mathrm{~cm}$ in length, presenting 2 or 3 flowers; cordate bracts, sessile to subsessile. Flowers yellow bisexual, diclamideous, pedicellate; pedicel $0.2-0.4 \mathrm{~cm}$ in length, pubescent, trichomes simple and stellate; calyx 2-3 mm long, deltoid sepals joined until the median region; corolla $1-1.2 \mathrm{~cm}$ long, yellowish, ovate lobes; ovary with 4 or 5 locules, 3 ovules per locule; numerous stamens, partially fused at the base of the fillet, forming an androphore, staminal column ca $2 \mathrm{~mm}$ in length. Schizocarp $0.7-0.9 \mathrm{~cm}$ in diameter, 5 mericarps, hairy to pubescent, capsules dehiscent, $0.8-0.9 \mathrm{~cm}$ in diameter; inconspicuous constriction; mericarps with bristles ca 1 $\mathrm{mm}$ in length. Seeds ovate, 3 per mericarp, 1-2 $\mathrm{mm}$ in length, pubescent. Flowers and fruits were observed in September.

\section{Discussion}

A specimen of $W$. hernandioides was collected from an open anthropized area, at the margin of a Caatinga fragment at the IPA Experimental Research Station of Caruaru, in the Agreste physiographic zone of Pernambuco. The site presents hypoxerophylic vegetation with arboreal-bush size in a good state of conservation. Several botanical studies have been carried out in this area, including the floristic study by Alcoforado-Filho et al. (2003), which recorded 96 species belonging to 41 families.

Wissadula hernandioides occurs in the Americas, i.e. in the United States of America, Mexico, West Indies, Venezuela, Colombia, Bolivia, Paraguay, Argentina and Brazil (Bovini and Baumgratz 2016). In Brazil, this species occurs in the northern (Pará and Roraima), northeastern (Bahia, Sergipe and Pernambuco - new record), mid-western (Mato Grosso do Sul and Mato Grosso), south-eastern (Espírito Santo, Minas Gerais, Rio de Janeiro and São Paulo) and southern (Paraná and Rio Grande do Sul) regions. In these regions, it is associated with the Amazon, Cerrado, Atlantic Forest, and Pantanal phytogeographic domains (BFG 2018), with a new record for Caatinga domain, herein. In the northeast, the species was only recorded in the Cerrado (Bahia) and Atlantic Forest (Sergipe) areas. In this study, we recorded $W$. hernandioides for the first time in the state of Pernambuco, located about $300 \mathrm{~km}$ from its closest previous record (Sergipe) (Fig. 2).

Wissadula hernandioides was recognized by the shape and margin of its leaf, constriction, and spines of the mericarps, as well as the indumentum of the branches and petioles. This species is easily confused with $W$. amplissima (L.) R.E.Fr., differing by the indumentum of the branches, which are hirtellous and simple 

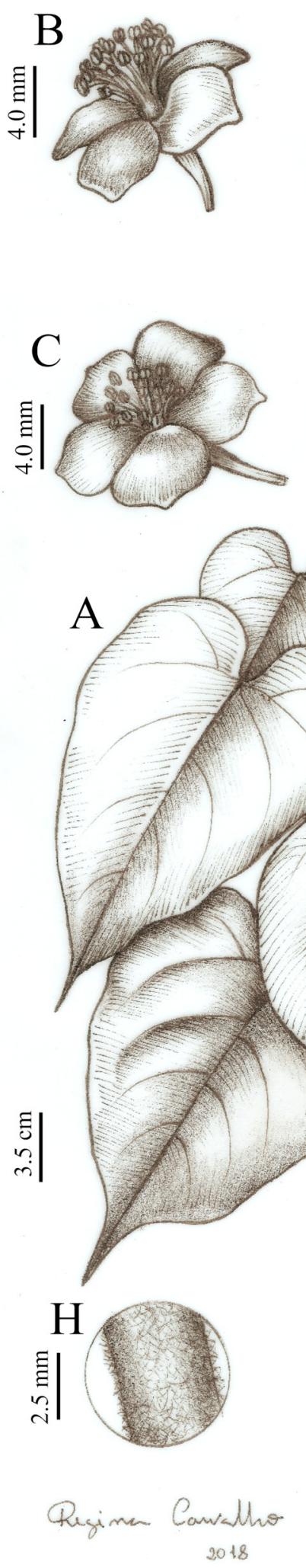
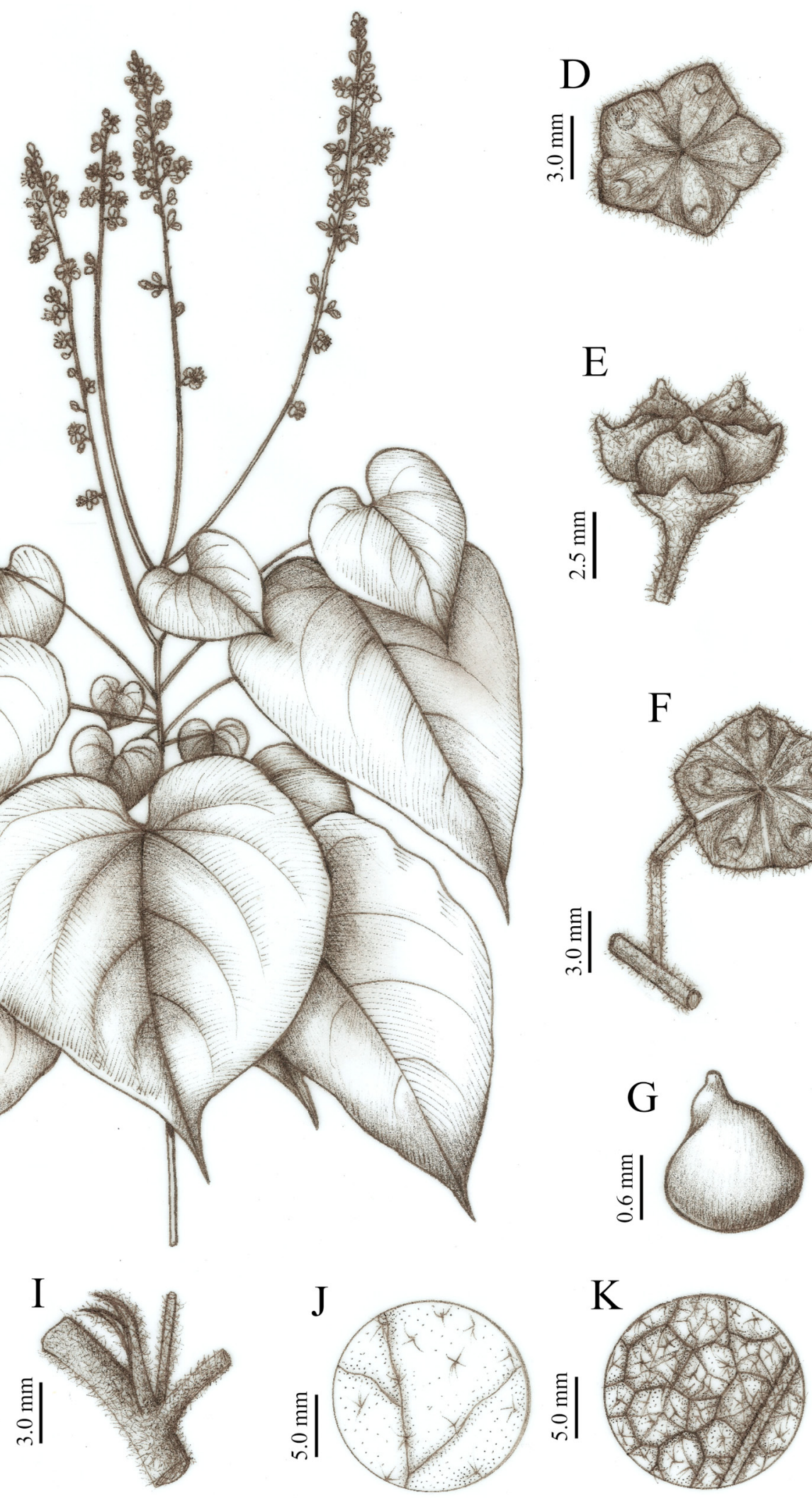

Figure 1. Wissadula hernandioides (L'Hér.) Garcke. A. Habit of a fertile branch. B, C. Details of the flowers. D, E. Details of the fruits. F. Detail of the fruit and pedicel showing the indumentum. G. Seed. H. Detail of the branch showing the indumentum. I. Detail of the stipules. J. Indumentum of the adaxial leaf surface. K. Indumentum of the abaxial leaf surface. 


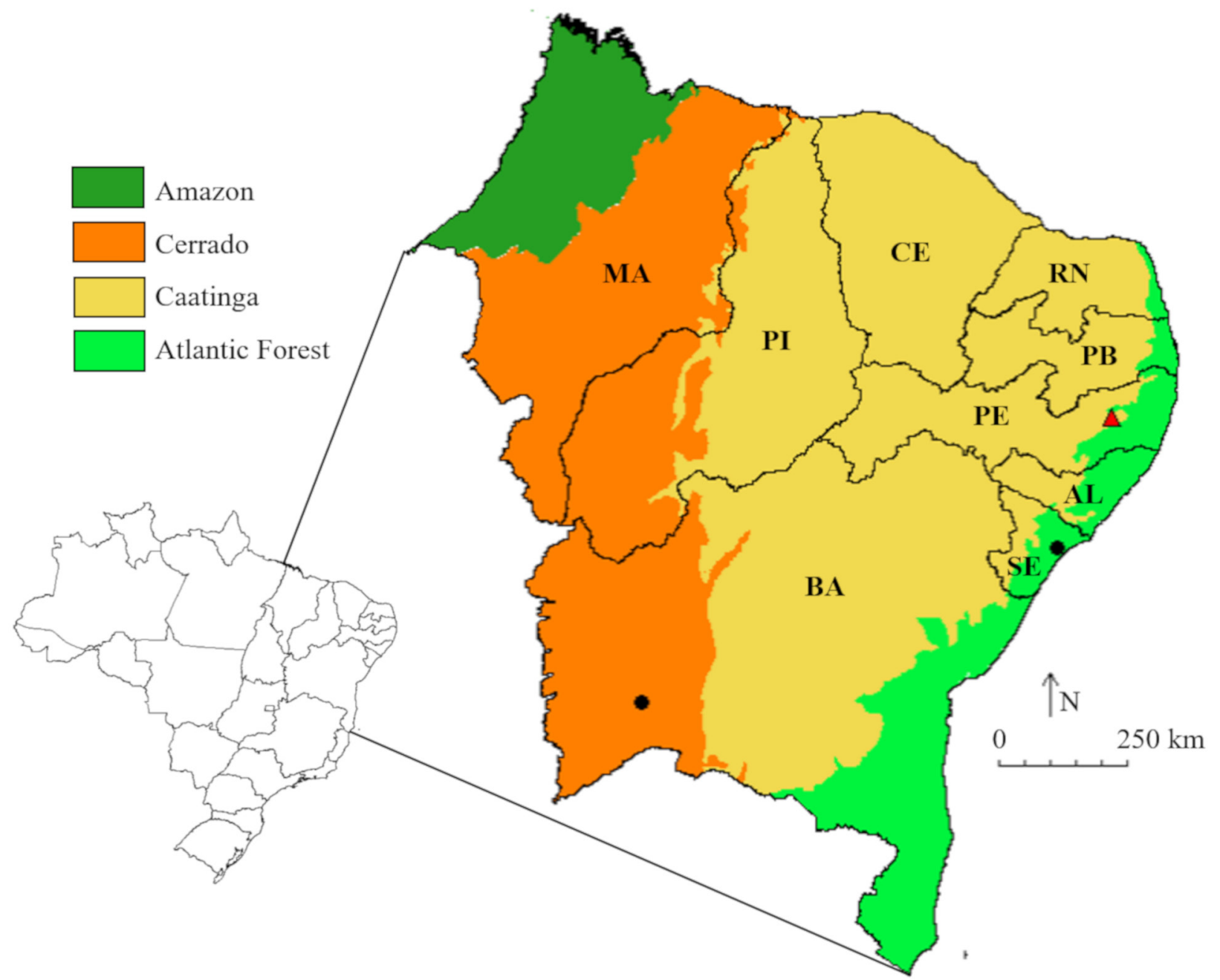

Figure 2. Map of the occurrence of Wissadula hernandioides (L'Hér.) Garcke in the Caatinga domain (red triangle) and previous records from northeastern Brazil for the Cerrado and Atlantic Forest domains (black points).

in $W$. amplissima and pubescent, simple and stellate in $W$. hernandioides. Through the confirmation of this new record, Wissadula is represented in the Caatinga domain and Pernambuco State by 6 species: $W$. amplissima, $W$. caribea (A. DC.) Bovini, W. contracta (Link) R.E.Fr., $W$. excelsior (Cav.) C.Presl., W. periplocifolia (L.) Thwaites, and now $W$. hernandioides.

Regarding conservation, the phytogeographic domain of the Caatinga has been neglected, with only $1 \%$ of its territory belonging to conservation units (Leal et al. 2005) and little research is carried out, due to the belief that it presents low biological diversity (Moro et al. 2016). However, contrary to expectations, the Caatinga presents high species richness with a high degree of endemism, including vegetation that is widely diversified with more than 4,600 species of angiosperms, $20 \%$ of which are endemic (BFG 2015). Nevertheless, research on the flora of the Caatinga is still insufficient when considering the high richness associated with its environments (Souza et al. 2015).

In this context, the new record of $W$. hernandioides for the Caatinga domain and Pernambuco State emphasizes the importance of expanding botanical collection efforts, especially in areas, as the Brazilian semi-arid, that are still unexplored from a floristic and taxonomic viewpoint. Furthermore, such increased collection efforts would help reinforce the importance of creating new conservation units in the Caatinga, as well as conserve and recover the biodiversity of this domain.

\section{Acknowledgements}

We thank to Regina Carvalho for the botanical illustrations, to the Experimental Research Station at the Agronomy Institute of Pernambuco in Caruaru for collection permission, to the Universidade Federal Rural de Pernambuco and the Graduate Program in Botany for the support and infrastructure. JIMM thanks to CNPq (Conselho Nacional de Desenvolvimento Científico e Tecnológico) for a Research Productivity Grant (PQ-2 process no. 303867/2015-9).

\section{Authors' Contributions}

CAA, ACF, RGVNL collected, herborized and identified the material. CAA created the distribution map. CAA, ACF, RGVNL, and JIMM wrote and discussed the manuscript. 


\section{References}

Alcoforado-Filho FG, Sampaio EVSB, Rodal MJN (2003) Florística e fitossociologia de um remanescente de vegetação caducifólia espinhosa arbórea em Caruaru, Pernambuco. Acta Botanica Brasilica 17(2): 287-303. http://doi.org/10.1590/S0102-33062003000200011

Areces F, Fryxell PA (2007) Malvaceae. In: Greuter W, RankinRodríguez R (Eds) Flora de la Republica de Cuba. Ser. A: Plantas Vasculares. Koeltz Scientific Books, Königstein, 228 pp.

Barroso GM, Morim MP, Peixoto AL, Ichaso CLF (1999) Frutos e sementes: morfologia aplicada à sistemática de dicotiledôneas. Editora UFV, Viçosa, 443 pp.

Bayer C, Kubitzki K (2003) Malvaceae. In: Kubitzki K, Bayer C. (Eds) The Families and Genera of Vascular Plants. Vol. 2. Flowering Plants, Dicotyledons: Expanded Caryophyllales, Capparales and Malvales. Springer, Berlin, 225-311.

Beentje H (2016) The Kew Plant Glossary: an Illustrated Dictionary of Plant Terms. 2nd edition. Kew Publishing, Richmond, 192 pp.

BFG (The Brazil Flora Group) (2015) Growing knowledge: an overview of Seed Plant diversity in Brazil. Rodriguésia 66 (4): 1085-1113. https://doi.org/10.1590/2175-7860201566411

BFG (The Brazil Flora Group) (2018) Brazilian Flora 2020: Innovation and collaboration to meet Target 1 of the Global Strategy for Plant Conservation (GSPC). Rodriguésia 69(4): 1513-1527. https://doi.org/10.1590/2175-7860201869402

Bovini MG (2015) Wissadula in Lista de Espécies da Flora do Brasil. Jardim Botânico do Rio de Janeiro. http://floradobrasil.jbrj.gov. br/jabot/floradobrasil/FB9290. Accessed on: 2018-09-06.

Bovini MG, Baumgratz JFA (2016) Taxonomic revision of Wissadula (Malvoideae, Malvaceae) in Brazil. Phytotaxa 243 (3): 201-234. http://doi.org/10.11646/phytotaxa.243.3.1

Fryxell PA (1988) Malvaceae of Mexico. Systematic Botany Mono- graphs 25: 1-522. http://doi.org/10.2307/25027717

Fryxell PA (1997) The American genera of Malvaceae II. Brittonia 49(2): 204-269. http://doi.org/10.2307/2807683

Iamonico D, Peruzzi L (2014) Typification of Linnaean names in Malvaceae for the Italian flora. Taxon 63 (1): 161-166. http://doi. org/10.12705/633.11

Judd WS, Manchester SR (1997) Circumscription of Malvaceae (Malvales) as determined by a preliminary cladistic analysis of morphological, anatomical, palynological, and chemical characters Brittonia 49 (3): 384-405. https://doi.org/10.2307/2807839

Leal IR, Silva JMC, Tabarelli M, Lacher Jr. TE (2005) Changing the course of biodiversity conservation in the Caatinga of northeastern Brazil. Conservation Biology 19 (3): 701-706. https://doi.org/ 10.1111/j.1523-1739.2005.00703.x

Moro MF, Lughadha EN, Araújo FS, Martins FR (2016) A Phytogeographical Metaanalysis of the Semiarid Caatinga Domain in Brazil. The Botanical Review 82 (2) 91-148. https://oi.org/10.1007/s 12229-016-9164-z

Santos DM, Santos JMFF, Silva KA, Araújo VKR, Araújo EL (2016) Composition, species richness, and density of the germinable seed bank over 4 years in young and mature forests in Brazilian semiarid regions. Journal of Arid Environments 129: 93-101. http://doi.org/10.1016/j.jaridenv.2016.02.012

Souza VC, Lorenzi H (2012) Botânica Sistemática: guia ilustrado para identificação das famílias de Fanerógamas nativas e exóticas no Brasil, baseado em APG III. 3rd edition. Instituto Plantarum, São Paulo, 768 pp.

Souza BIF, Artigas RC, Lima ERV (2015) Caatinga e desertificação. Mercator 14 (1): 131-150. http://doi.org/10.4215/RM2015.1401.0009 Stevens PF (2001) Angiosperm Phylogeny Website. Version 14, July 2017 [and more or less continuously updated since]. http://www. mobot.org/MOBOT/research/APweb/. Accessed on: 2019-03-19. 